\title{
TINJAUAN KONSEP BISNIS ISLAM TERHADAP ASPEK PEMASARAN
}

\author{
Budi Sufyanto ${ }^{1}$, Zainol Hasan ${ }^{2}$ \\ budisufyanto@gmail.com, ${ }^{1}$ hasansideas02@gmail.com² \\ Sekolah Tinggi Agama Islam Nurul Huda Kapongan Situbondo ${ }^{1}$ \\ Universitas Ibrahimy Situbondo ${ }^{2}$
}

\begin{abstract}
The purpose of this paper is to examine the concept of Islamic business in terms of marketing aspects. Islam basically allows humans to do marketing or business, and Islam views economic activity positively. This means that the more people involved in economic or business activities, the better the processes and goals are in accordance with Islamic teachings. However, of course people who run business in Islam, must use the rules of the game in Islam. In addition, in running a business, Islam emphasizes and directs the benefits or uses and always maintains the quality and existence of the product, prohibiting selling a product that is not clear (gharar) to buyers. Even Islamic businessmen are not only for profit, but none other than for getting blessings.
\end{abstract}

Keywords: Islamic Business Ethics and Marketing Aspects

\section{PENDAHULUAN}

Manusia sebagai makhluk sosial, salah satunya adalah untuk mendapatkan kebahagiaan. Manusia akan memperoleh kebahagian bila di dalam seluruh kebutuhan dan keinginan dalam hidupnya telah terpenuhi, baik dalam aspek material maupun spiritual. Dalam jangka pendek maupun jangka panjang Islam mempunyai pandangan terhadap harta dan ekonomi. Terpenuhinya kebutuhan yang bersifat material, seperti sandang, rumah, kekayaan dan lainya. Dalam konteks dewasa ini, kebutuhan material inilah yang disebut dengan sejahtera. Maka, hal tersebut lebih banyak mendapatkan perhatian, dan di dalam upaya mewujudkan kesejahteraan itu, manusia menghadapi kendala pokok, yaitu kurangnya sumberdaya yang bisa digunakan untuk mewujudkan kebutuhan tersebut.

Islam di dalam mengartikan atau mendefiinisikan agama bukan hanya berkaitan dengan spritualitas atau ritualitas semata, namun agama merupakan serangkaiaan keyakinan, ketentuan dan peraturan serta tututan moral bagi setiap 
aspek kehidupan manusia. Islam memandang agama adalah sebagai suatu jalan hidup yang melekat pada setiap aktivitas kehidupan, baik ketika manusia melakukan hubungan ritual dengan Tuhannya maupun ketika manusia berinteraksi dengan sesama manusia atau alam semesta. Manusia pada dasarnya menginginkan bagaimana pertumbuhannya meningkat, baik dibidang ekonomi ataupun dengan masyarakatnya oleh kerena itu setiap manusia pasti menginginkan kehidupan yang baik (Ahmad el-Najjar, 1972).

Islam memandang aktifitas ekonomi secara positif. Artinya semakin banyak manusia terlibat dalam aktivitas ekonomi, maka semakin baik pula, proses dan tujuan yang sesuai dengan ajaran Islam. Berbagai ahli ekonomi muslim memberikan definisi ekonomi Islam yang berfariasi, tetapi pada dasarnya mengandung makna yang sama. Pada intinya, ekonomi Islam adalah suatu cabang ilmu pengetahuan yang berupaya untuk memandang, menganalisis, dan akhirnya menyelesaikan permasalahan-permasalahan ekonomi dengan cara-cara yang Islami.

Islam sangat melarang akan adanya praktik yang dapat mengganggu mekanisme pasar seperti praktik mal bisnis. Mal bisnis merupakan semua perbuatan bisnis yang tidak baik, jelek (secara moral), membawa akibat buruk bagi pihak lain, serta perbuatan yang meliputi aspek hukum (pidana) yang disebut dengan business crimes atau busines tort. Business crimes adalah perbuatan tercela yang dilakukan oleh bisnismen atau pegawai suatu bisnis baik untuk bisnisnya maupun yang merugikan bisnis yang lain. Sedangkan Business tort adalah perbuatan yang tercela yang dilakukan oleh usahawan yang merupakan pelanggaran terhadap usaha lainnya (Muhammad Alimin, 2004).

Pemasaran bukan sekedar perluasan penjualan, tetapi pemasaran meliputi keseluruhan bisnis, dan harus dilihat dari sudut pelanggan. Hanya pemasaran dan inovasilah yang dapat menghasilkan uang, kegiatan yang lainnya adalah merupakan pos biaya saja. Paradigma pemasaran mengalami perubahan dari masa ke masa, konsumen yang dulunya selalu menggunakan pertimbangan rasional dalam memilih barang atau jasa, kini paradigma itu telah tergeserkan oleh pertimbangannya yang lebih luas.

\section{Pengertian Pemasaran}


Sebutan pemasaran dalam dalam English Language dikenal dengan nama markering. Kata marketing ini boleh dikata telah diserap ke dalam bahasa Indonesia, dan juga diterjemahkan dengan istilah pemasaran. Asal kata pemasaran adalah pasar (market). Apa yang dipasarkan itu, ialah barang dan jasa. Memasarkan barang tidak berarti hanya menawarkan barang atau menjual tetepi lebih luas dari itu. Misalnya di dalamnya tercakup berbagai kegiatan seperti membeli, menjual, dengan segala macam cara, mengangkut barang, menyimpan, mensortir, dan lain sebagainya. Di dalam marketing, usaha ini dikenal sebagai fungsi-fungsi marketing (Sofyan Assauri, 2008).

Pemasaran merupakan ruh dari institusi bisnis. Semua orang yang bekerja dalam Institusi tersebut adalah marketer yang membawa integritas, identitas dan image perusahaan serta bersikap profesional dalam dunia bisnis, karena dengan profesionalitas akan dapat menumbuhkan kepercayaan konsumen. Pemasaran adalah salah satu kegiatan dalam perekonomian yang membantu dalam menciptakan sebuah nilai ekonomi. Nilai ekonomi itu sendiri menentukan harga barang dan jasa. Faktor penting dalam menciptakan nilai tersebut adalah produk atau jasa, pemasaran dan konsumen. Pemasaran menjadi penghubung antara produk dan jasa yang dihasilkan oleh perusahaan dengan konsumen yang akan menggunakan produk atau jasa (Susatyo Herlambang \& Bambang Heru, 2014).

Pakar pemasaran dunia mendefinisikan pemasaran adalah merupakan salah satu instrumen terpenting dalam dunia bisnis untuk mencapai target pasar. Bahkan pemasaran merupakan kunci dari kesuksesan bisnis di era milenium ini. Kesuksesan bisnis sebuah perusahaan tergantung pada implementasi strategi pemasarannya dan kini pemasaran dianggap sebagai alat pemenuhan kepuasan konsumen (Philip Kotler \& Amstrong, 2012).

Tidak jauh berbeda dengan Philip Kotler dan Amstrong, William J Stanton mendifinisikan pemasaran adalah suatu sistem keseluruhan dari kegiatan-kegiatan bisnis yang ditujukan untuk merencanakan, menentukan harga, memperkenalkan dan memperdagangkan barang dan jasa yang memuaskan kebutuhan, baik itu kepada pembeli yang ada, maupun pembeli potensial (William J Stanton, 1993).

Saat ini kegiatan pemasaran mempunyai peranan yang sangat penting dalam dunia bisnis, istilah pemasaran sering diartikan dengan beberapa istilah, seperti: 
penjualan, perdagangan, atau distribusi. Pemasaran merupakan sebuah konsep yang menyeluruh dari kegiatan penjualan, perdagangan dan distribusi.

Misi pemasaran bukan sekedar menjadi salah satu anggota di dalam sebuah perusahaan, tetapi akan menjadi jiwa dan menjadi bagian dalam dirinya, karena setiap seksi atau orang dalam perusahaan harus paham dan menjadi unsur di dalam pemasaran. Dalam arti nilai bisnis, apapun yang dijalankan oleh pengusaha harus menganggapnya sebagai bisnis jasa, dan setiap orang dalam perusahaan harus merasa terlibat dalam proses pemuasan pelanggan. Baik langsung atau tidak, bukan hanya sebagai pelaksana yang digaji, tapi harus secara total melaksanakan pertambahan nilai dan memberi kepuasan kepada pelanggan.

\section{Pengertian Pemasaran dalam Islam}

Pemasaran Islami adalah sebuah disiplin bisnis strategis yang mengarahkan proses penciptaan, penawaran dan perubahan value dari suatu inisiator kepada stakeholders-nya, yang dalam keseluruhan prosesnya sesuai dengan akad dan prinsip-prinsip al-Qur'an dan Hadits (Bukhori Alma \& Doni Juni Priansa, 2014). Dengan demikian, dalam pemasaran Islami, seluruh proses baik penciptaan, penawaran maupun perubahan nilai (value), tidak boleh ada hal-hal yang bertentangan dengan akad dan prinsip-prinsip muamalah dalam Islam. Bila tidak demikian, maka tidak diperbolehkan (Hermawan Kertajaya \& Muhammad Syakir Sula, 2006).

Pentingnya pasar dalam Islam tidak terlepas dari fungsi pasar sebagai wadah bagi berlangsungnya kegiatan jual-beli. Keberadaan pasar yang terbuka memberikan kesempatan bagi masyarakat untuk ambil bagian dalam menentukan harga, sehingga harga ditentukan oleh kemampuan riil masyarakat dalam mengoptimalisasikan faktor produksi yang ada didalamnya (Heri Sudarsono, 2008).

Aang Kunaifi menyatakan bahwa pemasaran Islami atau yang ia sebut dengan spiritual marketing adalah upaya spiritualisasi atau penerapan nilai-nilai spiritual dalam setiap strategi, program dan nilai yang dijalankan dalam pemasaran. Nilai spiritual yang dimaksud adalah nilai-nilai religius atau aturan agama Islam yang bersumber dari al-Qur;an dan Hadits Habawi. Secara konsep, spiritual marketing merupakan tata olah cipta, rasa, hati dan karsa (implementasi) yang diimbangi oleh integritas keimanan dan ketaqwaan kepada Allah SWT. Pemahaman spiritual 
marketing dalam sudut pandang syariah adalah melakukan pembatasan terhadap orientasi material manusia yang cenderung tanpa batas, untuk memberikan ruang dan energi dalam merealisasikan semangat dan tujuan spiritual (Aang Kunaifi, 2016).

Pemasaran Islami merupakan aktivitas dalam kegiatan bisnis berbentuk kegiatan penciptaan nilai (value creating activities) yang memungkinkan siapa saja yang melakukannya dapat tumbuh serta mendayagunakan manfaatnya yang dilandasi atas sifat jujur, adil, terbuka, dan ikhlas sesuai dengan proses yang berprinsip pada akad untuk bermuamalah secara Islami atau perjanjian transaksi bisnis dalam Islam. Pemasaran tersebut berhubungan dan berkaitan dengan suatu proses mengidentifikasi dan memenuhi kebutuhan manusia dan masyarakat (Tamamuddin, 2014).

Konsep Islam memahami bahwa pasar dapat berperan efektif dalam kehidupan ekonomi bila prinsip persaingan bebas dapat berlaku secara efektif. Pemasaran Islami adalah perusahaan yang tidak berhubungan dengan bisnis yang mengandung unsur-unsur yang dilarang menurut syariah, yaitu judi, riba, dan produk-produk yang diharamkan. Namun, walaupun bisnis perusahaan tersebut tidak berhubungan dengan kegiatan bisnis yang diharamkan, terkadang taktik yang digunakan dalam memasarkan produk- produknya masih menggunakan cara-cara yang diharamkan dan tidak etis.

Banyak ahli yang memberikan definisi tentang pemasaran tetapi defnisi yang diberikan sering berbeda antara ahli yang satu dengan ahli yang lain. Perbedaan ini disebabkan karena perbedaan para ahli tersebut dalam memandang dan meninjau tentang pemasaran. Dalam kegiatan pemasaran, aktifitas pertukaran merupakan hal utama. Pertukaran merupakan kegiatan pemasaran dimana seseorang berusaha menawarkan sejumlah produk atau jasa dengan sejumlah nilai manfaat keberbagai macam individu maupun kelompok sosial untuk memenuhi keinginan dan kebutuhannya. Pemasaran sebagai kegiatan manusia diarahkan untuk memuaskan keinginan (wants) dan kebutuhan (needs) manusia setiap hari melalui proses pertukaran.

Dalam pemasaran Islami terdapat empat karakteristik yang dapat menjadi panduan bagi para pemasar, yaitu : 
1. Teistis (rabbaniyah) merupakan salah satu ciri khas syariah marketing yang tidak dimiliki dalam pemasaran konvensional yang selama ini dikenal yang sifatnya religus (diniyah).

2. Etis (akhlaqiyah), keistimewaan yang lain dari syariah marketing selain karena teitis (rabbaniyah), juga karena syariah marketing mengedepankan masalah akhlaq (moral, etika) dalam seluruh aspek kegiatannya.

3. Realistis (al-waqi'iyah) adalah merupakan kenyataan yang sesungguhnya. Artinya semua transaksi selalu berlandaskan dengan kejujuran. Hal ini sesuai dengan yang telah diajarkan oleh Rasulullah SAW terkait dengan sifat realistis.

4. Humanistis (al-insaniyyah) artinya berperikemanusiaan, yaitu syariat Islam diciptakan untuk manusia sesuai dengan kapasitasnya, tanpa menghiraukan adanya perbedaan serta mengedepankan prinsip simbiosis-mutualisme (Hermawan Kertajaya \& Muhammad Sakir Sula, 2006).

\section{Konsep Pemasaran}

Konsep pemasaran bertujuan memberikan kepuasan terhadap keinginan dan kebutuhan pembeli atau konsumen. Seluruh kegiatan dalam perusahaan yang menganut konsep pemasaran harus diarahkan untuk memenuhi tujuan tersebut. Kegiatan dalam konsep inti pemasaran meliputi kegiatan pada bagian yang ada, seperti kegiatan personalia, produksi, keuangan, serta fungsi-fungsi yang lain yang mengarahkan kepada pemenuhan keinginan dan kebutuhan pembeli atau konsumen. Konsep-konsep dalam pemasaran diantaranya (Buchari Alma dan Doni Juni Priansa, 2014).

\section{Konsep Produksi (The Production Concept)}

Konsep Poduksi bertitik tolak dari adanya anggapan bahwa konsumen menginginkan adanya produk yang berharga dan murah serta mudah untuk mendapatkannya. Bahkan menghendaki agar gampang untuk mendapatkan dimanamana. Produsen yang menganut konsep ini, akan membuat produksi secara massal, menekan biaya dengan efisiensi tinggi sehingga harga pokok pabrik bisa ditekan dan harga jual lebih rendah dari saingan. Konsep produksi, perusahaan hanya berorientasi kepada jumlah produksi dan konsumen diharapkan akan menyukai produk yang telah disediakan oleh perusahaan. Selain itu, konsumen diharapkan akan membeli produk 
tersebut sesuai dengan kemampuan daya belinya sehingga kualitas produk tidak menjadi prioritas utama (Susatyo Herlambang \& Bambang Heru Marwoto, 2014).

2. Konsep Produk (The Product Concept)

Konsep produk adalah sebuah konsep yang menitik beratkan kepada kualitas hasil produk. Konsumen akan menyukai produk yang menawarkan kualitas dan prestasi terbaik serta keistimewaan yang menonjol. Produsen berupaya memperbaiki produk terus-menerus serta meningkatkan jumlah produksinya tanpa memperhatikan permintaan produk dipasar.

3. Konsep Penjualan

Konsep Penjualan merupakan konsep yang memperhatikan jumlah permintaan pasar untuk sebuah produk, dan perusahaan akan memproduksi sebuah produk disesuaikan dengan kenginan pasar.

4. Konsep Kemasyarakatan

Konsep ini lebih dominan terhadap tingkat orientasi pada rasa tanggungjawab sosial dan kemanusiaan didasarkan atas banyaknya kritik dan sorotan dari luar perusahaan. Baik yang datang dari pemerintah maupun dari masyarakat melalui lembaga konsumen, atau LSM maka peusahaan harus memiliki rasa tangung jawab moral untuk melayani masyarakat dengan sebaikbaiknya.

Menurut Boonee dan Kurtz dalam Sudaryono bahwa pemasaran adalah suatu proses perencanaan dan pelaksanaan pemikiran, harga, promosi, distribusi atas ide, barang jasa, organisasi, dan peristiwa untuk menciptakan serta memelihara hubungan yang akan memuaskan bagi tujuan perorangan dan organisasi (Sudaryono, 2016). 


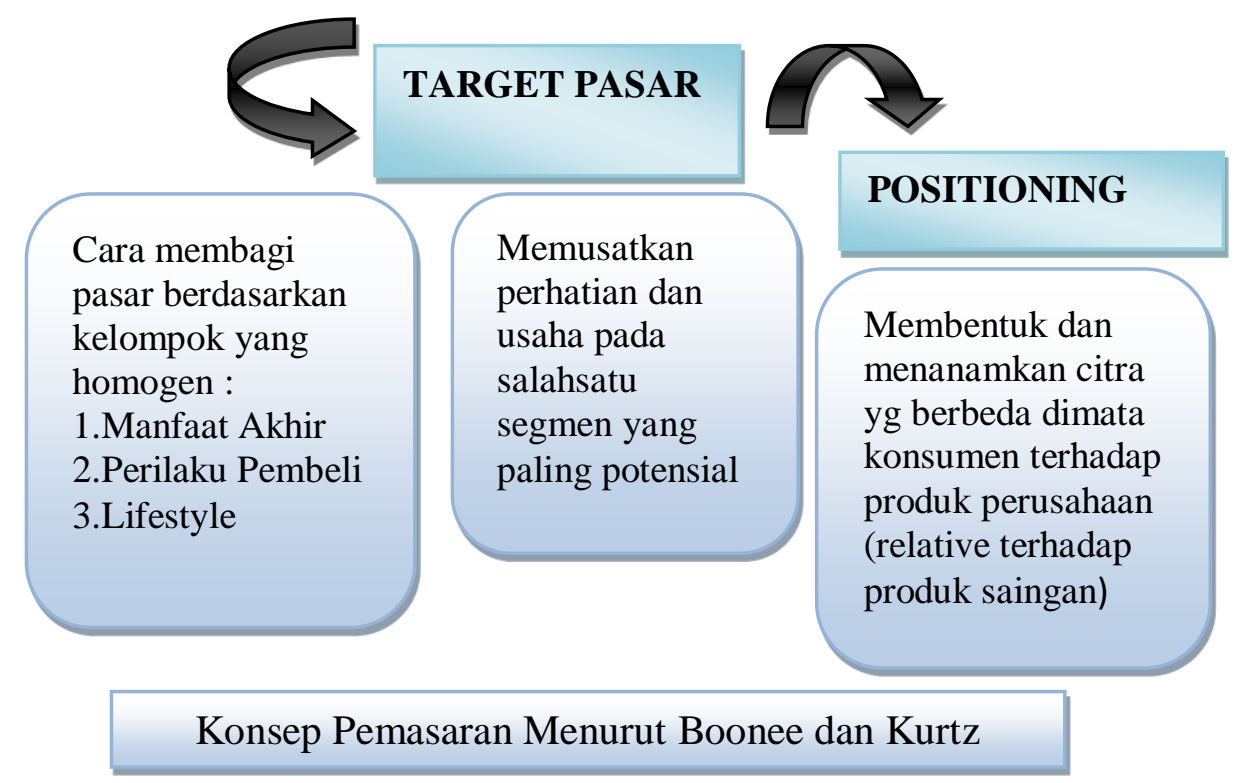

Gambar diatas memberikan penjelasan setelah perusahaan mengetahui kondisi pasar dengan jalan melakukan pengukuran pasar (biasanya melalui riset pasar), perusahaan kemudian melakukan segmentasi pasar, yakni membagi pasar berdasarkan kelompok yang homogeny atau berdasarkan kategori tertentu, misalnya berdasarkan manfaat, perilaku pembeli atau gaya hidup (lifestyle) konsumen.

Sesudah itu, perusahaan membuat target pasar yang pada nantinya akan memusatkan perhatian pada salah satu segmen yang dipandang paling potensial. Jika sudah berhasil, biasanya perusahaan melakukan pemosisian diri (positioning). Positioning merupakan langkah perusahaan guna membentuk dan menanamkan citra (image) yang berbeda dimata konsumen terhadap produk perusahaan yang menjadi faktor pembeda dengan perusahaan pesaing, baik secara relatif maupun secara absolut.

\section{Konsep Pemasaran dalam Islam}

Perspektif Islam, konsep pemasaran adalah salah satu diantara hal yang paling penting dalam menjalankan sebuah usaha atau bisnis. Bahkan, al-Qur'an menggunakan konsep pemasaran dalam arti yang sangat luas. Misalnya, tekanan al-Qur'an diarahkan pada manfa'at atau kegunaan yang diproduksi, dan memproduksi barangnya pun harus mempunyai hubungan dengan kebutuhan manusia. Bahkan sejak zaman Nabi Muhammad SAW telah mengajarkan tentang cara pemasaran yang sesuai dengan ajaran Islam, termasuk dalam ruang lingkup bisnis (Abdurrahman Zen, 2011). 
Tak bisa dipungkiri, cikal bakal konsep pemasaran dalam Islam dapat dilacak atau dilihat dari praktik bisnis Nabi Muhammad SAW dan para saudagar Muslim terdahulu. Misalnya praktik pemasaran yang dilakukan oleh Nabi dengan cara jujur, mencintai customer, penuhi janji dan tepat waktu. Nabi pun memiliki sifat-sifat mulia yang mendukung dan mendorong keberhasilan bisnisnya, seperti siddik (jujur atau benar), amanah (dapat dipercaya), tabligh (argumentatif dan komunikatif) dan fathonah (cerdas dan bijaksana) (Abdurrahman Zen, 2011).

Sebenarnya konsep pemasaran syariah sendiri tidak berbeda jauh dari konsep pemasaran yang kita kenal selama ini. Konsep pemasaran yang kita kenal sekarang, pemasaran adalah sebuah ilmu dan seni yang mengarah pada proses penciptaan, penyampaian, dan pengkomunikasian values kepada para konsumen serta menjaga hubungan dengan para stakeholders-nya (Nilam Sari, 2012).

Walaupun demikian, menurut Hermawan Kartajaya ada sebuah kelirumologi yang diartikan untuk membujuk orang belanja sebanyak-banyaknya atau pemasaran yang pada akhirnya membuat kemasan sebaik-baiknya padahal produknya tidak bagus. Bahkan membujuknya pun dengan segala cara agar orang mau bergabung dan belanja. Diantara perbedaannya adalah pemasaran syariah mengajarkan pemasar agar selalu menjaga kualitas dan keberadaan produk, melarang jual-beli suatu produk yang belum jelas (gharar) bagi pembeli, jujur pada konsumen atau orang lain, dan nilai-nilai syariah mencegah pemasar terperosok pada kelirumologi itu, karena ada nilai-nilai yang harus dijunjung oleh seorang pemasar atau pembisnis (Hermawan Kartajaya \& Muhammad Syakir Sula, 2006). Konsep Pemasaran Syariah menurut Hermawan dan Syakir Sula diantaranya adalah:

1. Syariah Marketing Strategy, untuk memenangkan mind-share, dapat dilakukan pemetaan pasar berdasarkan pertumbuhan pasar, keunggulan kompetitif dan situasi persaingan. Dari pemetaan potensi pasar sebelumnya, dapat dilihat bahwa pasar rasional atau pasar mengambang merupakan pasar yang sangat besar. Para pebisnis harus dapat membidik pasar rasional yang sangat potensial tersebut. Setelah itu, mereka perlu melakukan positioning sebagai perusahaan yang mampu meraih mindshare.

2. Syariah Marketing Tactic, untuk memenangkan market-share. Ketika positioning pebisnis syariah di benak pasar rasional telah kuat, mereka harus melakukan diferensiasi yang mencakup apa yang ditawarkan (content), bagaimana menawarkan 
(context) dan apa infrastruktur dalam menawarkannya. Langkah selanjutnya, para marketer perlu menerapkan diferensiasi secara kreatif dan inovatif dengan menggunakan marketing mix (price, product, place and promotion). Hal-hal yang perlu dipersiapkan juga, bagaimana pebisnis melakukan selling dalam meningkatkan hubungan dengan pelanggan sehingga mampu menghasilkan keuntungan finansial.

\section{KESIMPULAN}

Tak terbantahkan bahwa kajian bisnis Islam terhadap aspek pemasaran masih kategori minim. Bahkan dalam praktiknya lebih dominan secara konvensional. Indonesia, negara yang mayoritas penduduknya menganut agama Islam seharusnya bisnis Islam lebih sangat diterapkan ketimbang negara lain. Tentu ketika melakukan sebuah transaksi bisnis Islam tersebut berpegang teguh terhadap norma dan aturan main yang telah digariskan oleh Islam sebagai pijakan. Aspek pemasaran Islam disini bisa menarik apabila dikaji dan dikembangkan di masa yang akan datang. Tujuannya, tiada lain agar dapat dipahami, diamalkan dan dipraktikkan oleh masyarakat luas, khususnya bagi para manajer muslim yang mempunyai sebuah perusahaan.

\section{Daftar Pustaka}

Arifin, Johan, Etika Bisnis Islami, Semarang: Walisongo Press, 2009.

Assauri, Sofyan, Manajeman Pemasaran, Edisi Pertama Cetakan Kedelapan, Jakarta : Raja Grafindo, 2008.

Beekum, Rafik Issa, Etika Bisnis Islami, Yogyakarta: Pustaka Belajar, 2004.

Buchari Alma dan Doni Juni Priansa, Manajemen Pemasaran dan Pemasaran Jasa, Bandung : Alvabeta CV, 2014.

El-Najjar, Muhammad, Bank Bila Fawaid ka Istiratijiyah lil Tanmiyyah alIqtishadiyyah, Jeddah: King Abdul Aziz University Press, 1972.

Herlambang, Susatyo \& Heru Marwoto, Bambang, Pengantar Ilmu Bisnis, Yogyakarta : Parama Publishing, 2014.

Kartajaya, Hermawan dan Syakir Sula, Muhammad, Syariah Marketing, Bandung: PT Mizan Pustaka, 2006.

Kunaifi, Aang, Manajemen Pemasaran Syariah Pendekatan Human Spirit : Konsep, Etika, Strategi dan Implementasinya, Yogyakarta : Maghza Pustaka : 2016. Media Syariah, Vol XIV No. 2 Juli - Desember 2012. 
Volume 2, No 1, Februari 2021

Stanton, William J., Prinsip-Prinsip Pemasaran, ed. 7 Jilid 2, Jakarta : Erlangga, 1993.

Sudaryono, Heri, Konsep Ekonomi Islam Suatu Pengantar, Yogyakarta ; UII 2008.

Sudaryono, Manajeman Pemasaran Teori dan Implementasi, Yogyakarta : CV Andi, 2016.

Zen, Abdurahman, Strategi Genius Marketing ala Rasulullah, Yogyakarta : DIVA Press, 2011.

Jurnal al-Idārah | 122 